\title{
AZ EURÓPAI VÉDELMI ÜGYNÖKSÉG SZEREPE A MAGYAR HONVÉDSÉG FORGÓSZÁRNYAS HARCÁSZATI KIKÉPZÉSI KÉPESSÉGEINEK FEJLESZTÉSÉBEN
}

DOI: 10.35926/HSZ.2020.2.7

\begin{abstract}
ÖSSzEFOGLALÓ: A tanulmány azt vizsgálja, hogy az Európai Védelmi Ügynökség (EDA) által kezdeményezett magyar vonatkozású programok milyen hatással voltak és vannak a Magyar Honvédség (MH) forgószárnyas képzéseire. Bemutatja, hogy a nemzetközi szereplők milyen együttmüködési folyamat eredményeként jutottak el a mai integrált kiképzési formákig, és ezek milyen eredményekkel járultak hozzá a nemzeti képesség fejlesztéséhez. A szerző arra hívja fel a figyelmet, hogy a programokban történő részvétel messze nem anyagi ráfordítás kérdése, hanem mindinkább a szakmai tapasztalatok és a rendelkezésre álló képességek megfelelő megosztása és felhasználása. A kor kihivásainak megfelelni képes kiképzési rendszer kialakitásához és magas színvonalon tartásához az Ügynökséggel történő még szorosabb együttmüködésre van szükség, ehhez a szerző javaslatokat is megfogalmaz.
\end{abstract}

kULCSSZAVAK: Európai Védelmi Ügynökség, Magyar Honvédség, helikopter, harcászati kiképzés

\section{BEVEZETÉS}

Az Európai Unió (EU) a geopolitikai helyzetéből adódóan, valamint a biztonsági kihívásokban bekövetkezett változások - illegális bevándorlás, erősödő orosz fenyegetés, az amerikai elnökválasztás keltette bizonytalanság a transzatlanti kapcsolatokban, a német és a francia választások, a brexit - miatt elkezdett kialakítani egy olyan feltételrendszert, hogy komoly tényezővé váljon a nemzetközi politikai és hadiipari porondon, és ezzel nagyobb felelősséget vállaljon saját biztonságának szavatolásában. A biztonság szavatolásának egyik sarkalatos pontja az európai nemzetek katonai képességeinek a fejlesztése és a kialakított képességek fenntartásához szükséges magas szintü kiképzés lehetőségének a megteremtése.

Mára már nyilvánvaló, hogy az állami érdekeink elleni kihívások elválaszthatatlanul összeforrnak szövetségi rendszerünknek a NATO és az EU egészét érintő mindazon biztonsági fenyegetésekkel, amelyek hatásait tekintve közvetetten országunkra is hatnak. Magyarország a transzatlanti szövetségi kapcsolatok és az Európai Unióval történő együttmüködés révén igyekszik biztosítani saját biztonságát és stabilitását. Az MH a Zrínyi 2026 Honvédelmi és Haderőfejlesztési Program keretében tervezi a hiányzó képességek kialakítását és

\footnotetext{
European Defence Agency.
} 
a meglévő képességeinek a fejlesztését. A program keretében nagy mennyiségü, a kor színvonalának megfelelő haditechnikai eszköz kerül beszerzésre. A legújabb generációs technikai eszközök nemcsak magas színvonalú hozzáértést, képzettséget, de filozófiaváltást is igényelnek az alkalmazó és a felhasználó részéről egyaránt.

A katonai erő nem veszíti el jelentőségét a biztonság egyéb tényezőinek előtérbe kerülésével sem, sőt egyre újabb célokkal, előre nem látott területeken és nem hagyományos módon is sor kerülhet alkalmazására. A jövő harcterein a parancsnokoknak már nem egyszerủen az ellenség legyőzésére kell törekedniük, hanem úgy kell befolyásolniuk valamennyi résztvevő és szereplő akaratát és viselkedését, hogy a konfliktus mélyben húzódó okait is kezeljék, és így tartós megoldást érjenek el a győzelemmel. Ez az átfogó megközelítés megköveteli a katonai kiképzési erőfeszítések összehangolását más hatóságokkal és szervezetekkel, de egyben azt is jelenti, hogy a parancsnokok és a csapatok ma már korszerü kiképzési lehetöségekkel rendelkeznek. ${ }^{2}$

\section{AZ EDA SZERVEZETI FELÉPÍTÉSE, MŰKÖDÉSE, TEVÉKENYSÉGE}

Az Ügynökséget 2004-ben azért hozták létre a részt vevő tagországok, hogy az támogassa őket a katonai válságkezelési képességek fejlesztésében. ${ }^{3}$ Az EDA többnemzeti programokat és projekteket javasol és készít elő annak érdekében, hogy a tagországi erőfeszítések elmozduljanak a többnemzetiség irányába, mintegy katalizátorként müködve az európai védelmi szektor és az EU-szintü katonai képességhiányok megszüntetése területén.

Az EDA fogja össze az európai védelmi együttmüködéssel kapcsolatos tevékenységek nagy részét. Szakmai tapasztalatainak és hálózatainak köszönhetően tevékenysége a védelem széles spektrumát lefedi, melyek között fontos szerepet töltenek be a közös biztonság- és védelempolitikai müveleteket támogató kiképzések és gyakorlatok. Együttmüködési projektek révén segíti a munkát a résztvevők által közösen meghatározott prioritási területeken. A szervezet mottója a rugalmasság, a szakértelem és a költséghatékonyság mellett az „Együtt egy erősebb Európáért” (Together for a stronger Europe). ${ }^{4}$

Az EDA tevékenységének központi eleme a képességfejlesztési és a védelmi prioritások azonosítása. Az európai katonai képességfejlesztés prioritásait meghatározó Képességfejlesztési Terv $\left(\mathrm{CDP}^{5}\right)$ egy átfogó stratégiai eszköz, amelyet az EDA 2007 óta a tagállamokkal együtt dolgoz ki, és fontos kiegészítője az átfogó képességfejlesztési folyamatnak.

Az EDA az égisze alatt folyó, szintén többnemzeti fejlesztési projektekre nem tud kiegészítő forrást adni, azok teljes egészében az adott program tagállamai által az adott projektre összeadott hozzájárulásokból valósulnak meg. Az EDA pluszpénzekkel nem, csak úgynevezett nem piactorzító pénzügyi ösztönzőkkel tudja segíteni a tagállamok többnemzeti keretben folyó képességfejlesztési és beszerzési projektjeit. ${ }^{6}$

2 Ált/24. MH Kiképzési Doktrína. Magyar Honvédség, 2012.

3 Jelenleg - Dánia kivételével - az összes EU-tagállam a tagja. European Defence Agency: Member States. https:// eda.europa.eu/Aboutus/who-we-are/member-states (Letöltés időpontja: 2020. 01. 27.)

4 European Defence Agency: Together for a stronger Europe. 2012. https://www.eda.europa.eu/docs/eda-publications/eda-corporate-brochure (Letöltés időpontja: 2020. 01. 27.) DOI: 10.2836/12612

5 Capability Development Plan.

6 Council Decision 2011/411/CFSP of 12 July 2011 defining the statute, seat and operational rules of the European Defence Agency and repealing Joint Action 2004/551/CFSP. Official Journal of the European Union, 13. 07. 2011. https://www.eda.europa.eu/docs/documents/eda_council_decision.pdf (Letöltés időpontja: 2020. 01. 27.) 
Az Ügynökség az EU Bizottság politikai felügyelete és irányítása alatt működik. Vezetője az Unió külügyi és biztonságpolitikai főképviselője. Az Ügynökség vezérigazgatója felelős a szervezet munkájának felügyeletéért és koordinálásáért. A vezérigazgató közvetlen alárendeltségébe tartozik a Stratégia és Irányelv Egység $\left(\mathrm{SPU}^{7}\right)$, amely a vezérigazgató és helyettesének a munkáját támogatja. Az iparral, szinergiákkal és kidolgozókkal (ISE ${ }^{8}$ ) foglalkozó igazgató felelős a kapcsolatok erősítéséért az ipari szereplőkkel, az egyes EU-szabályozók hatásának vizsgálatáért, harmonizációjáért, valamint a katonai légi közlekedéssel és a kulcsfontosságú képességfokozókkal kapcsolatos tevékenységek összehangolásáért. A képességgel, fegyverzettel és tervezéssel $\left(\mathrm{CAP}^{9}\right)$ megbízott igazgató felelős a CDP kidolgozásáért, a koordinált éves védelmi felülvizsgálat $\left(\mathrm{CARD}^{10}\right)$ koordinálásáért, valamint ez az igazgatóság látja el az állandó strukturált együttmüködés $\left(\mathrm{PESCO}^{11}\right)$ titkársági feladatköréből adódó tevékenységeket is. A kutatás-fejlesztéssel kapcsolatos tevékenységekért a kutatással, technológiával és innovációval (RTI $\left.{ }^{12}\right)$ megbízott igazgató felel. A Vállalati Szolgáltatási Igazgatóság $\left(\mathrm{CSD}^{13}\right)$ funkcionális feladatokat lát el, felelős az Ügynökség technikai, személyügyi és pénzügyi támogatásáért.

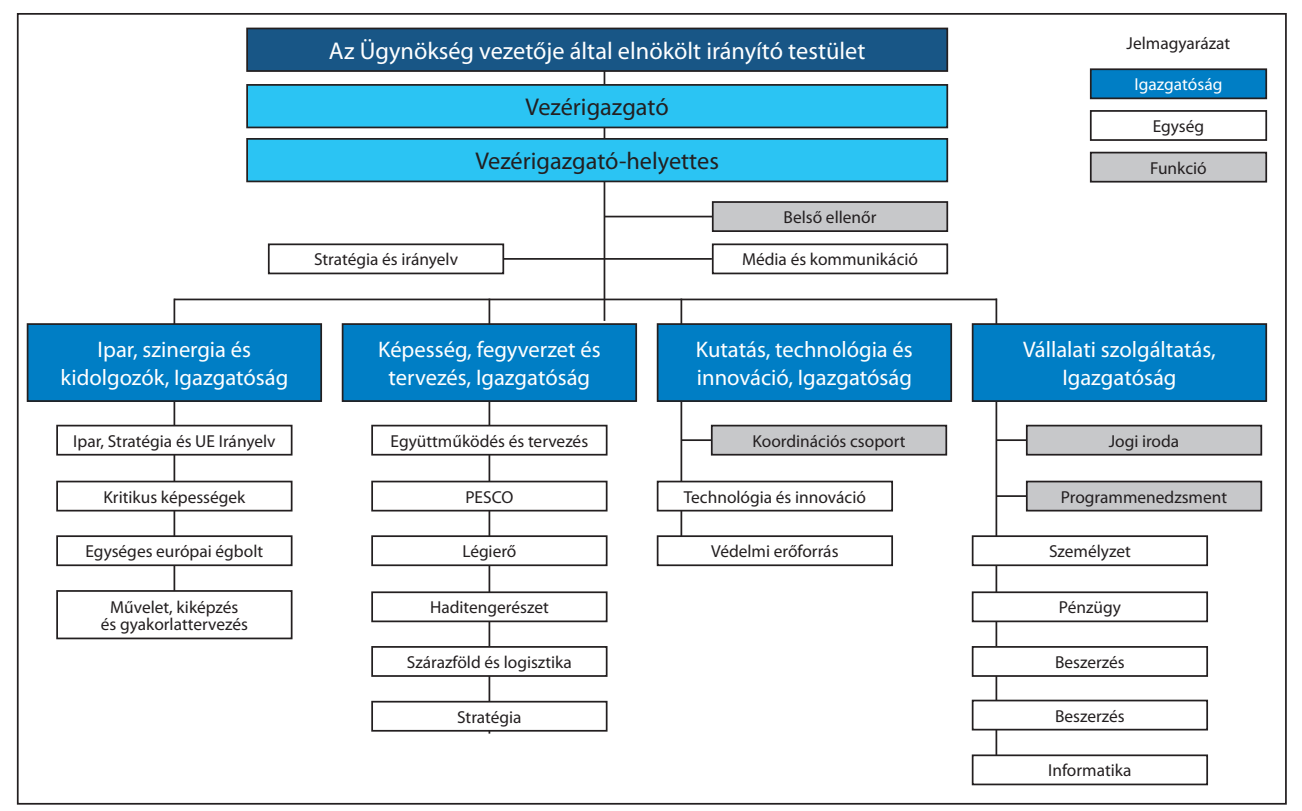

1. ábra Az EDA szervezeti felépitése ${ }^{14}$ (Szerkesztette a szerzö)

${ }^{7}$ Strategy and Policy Unit.

${ }^{8}$ Industry, Synergies and Enablers.

${ }^{9}$ Capability, Armament and Planning.

${ }^{10}$ Coordinated Annual Review on Defence.

${ }^{11}$ Permanent Structured Cooperation.

${ }^{12}$ Research, Technology and Innovation.

${ }^{13}$ Corporate Services Directorate.

${ }^{14}$ European Defence Agency: Organisation. https://www.eda.europa.eu/Aboutus/who-we-are/Organisation (Letöltés időpontja: 2019. 10. 17.) 
Oktatás, képzés és gyakorlatok terén az EDA változatos képzési és gyakorlati tevékenységeket folytat a csúcskategóriás katonai képességek támogatására, mint például a forgószárnyas és a katonai légi szállítással kapcsolatos kiképzés. Az Ügynökség előkészítő munkáját követően a 2017-ben Zaragozában (Spanyolország) létrehozott Európai Harcászati Légi Szállítási Központ (ETAC ${ }^{15}$ ) 2019-ig elérte a teljes müveleti képességet. Jelenleg az ETAC négy oktatói és négy végrehajtói tanfolyamot, valamint különböző továbbképzéseket szervez szállító repülőgépek személyzetei számára. Az EDA közvetlen támogatásával szimpóziumokat szerveznek, és támogató szerepe magában foglalja a katonai légi jármúvek személyzetei közös képzési tevékenységeinek a megkönnyítését és fejlesztését is.

Az új tevékenységi körök között van a pilótaképzés. Ennek célja a légi jármúvekre vonatkozó közös kiképzési programok és közös platformok kidolgozása a katonai pilóták képzésének szabványosításához, valamint egy közös müszaki kiszolgálási rend kidolgozása, ami fokozottabban ösztönzi a keresztkiszolgálást a nemzeti és a nemzetközi gyakorlatokon. Folytatódik a személyzetek közös képzése és a meglévő létesítmények karbantartását elősegítő európai Spartan B kategóriás (CAT B) ${ }^{16}$ program, valamint az European Spartan gyakorlat támogatása. 2018 folyamán 11 tanfolyamot szerveztek a helikopterszemélyzetek harcászati képzésével, az összetett légi müveletekkel $\left(\mathrm{COMAO}^{17}\right)$ és az elektronikai hadviseléssel $\left(\mathrm{EW}^{18}\right)$ kapcsolatban.

Az EDA helikopterprogramjai szintén támogatják az összevonás és a megosztás (pull and sharing) szinergiáit, elsősorban a kiképzési eszközökkel, a területekkel és az oktatókkal kapcsolatban, és elősegítik az európai helikopterszemélyzetek harcászati képzésének szabványosítását a 15 hozzájáruló tagállam között. Az ETAC-hoz hasonló megközelítést követve az Ügynökség támogatta a 2021-ig létrehozandó új Többnemzeti Helikopteres Kiképző Központ $\left(\mathrm{MHTC}^{19}\right)$ koncepciófejlesztési munkáját is.

A helikopterképesség kulcsfontosságú tényezővé vált a modern válságkezelési müveletekben, különösen az aszimmetrikus tevékenységek elleni küzdelem során. Bár az EU országai jelentős számú forgószárnyas repülöeszközzel rendelkeznek, az egyre több és egymást szorosan követő müveletekben nem volt elegendő a helikoptertámogatás. A tagállamokkal konzultálva megállapítást nyert, hogy számos kulcsfontosságú terület járul hozzá a támogatottság elmaradásához, mint például a személyzetek képzésének hiánya, a repülőeszköz előírt felszereltségének a hiányosságai és a telepített erők logisztikai támogatásának nehézségei. Az EDA segítséget nyújt a részt vevő tagállamoknak e hiányosságok megszüntetésében, a képzés fontosságára összpontosítva. ${ }^{20}$

\footnotetext{
15 European Tactical Airlift Centre.

${ }^{16}$ Council Joint Action 2004/551/CFSP of 12 July 2004 on the establishment of the European Defence Agency. Official Journal of the European Union, 17. 07. 2004. https://eur-lex.europa.eu/legal-content/EN/TXT/PDF/?uri=CELEX:32004E0551\&from=EN (Letöltés időpontja: 2020. 01. 27.)

${ }^{17}$ Composite Air Operations.

18 Electronic Warfare.

19 Multinational Helicopter Training Centre.

${ }^{20}$ European Defence Agency: Helicopter Initiatives. 02. 07. 2017. https://www.eda.europa.eu/what-we-do/activities/activities-search/helicopter-initiatives (Letöltés időpontja: 2019. 11. 07.)
} 


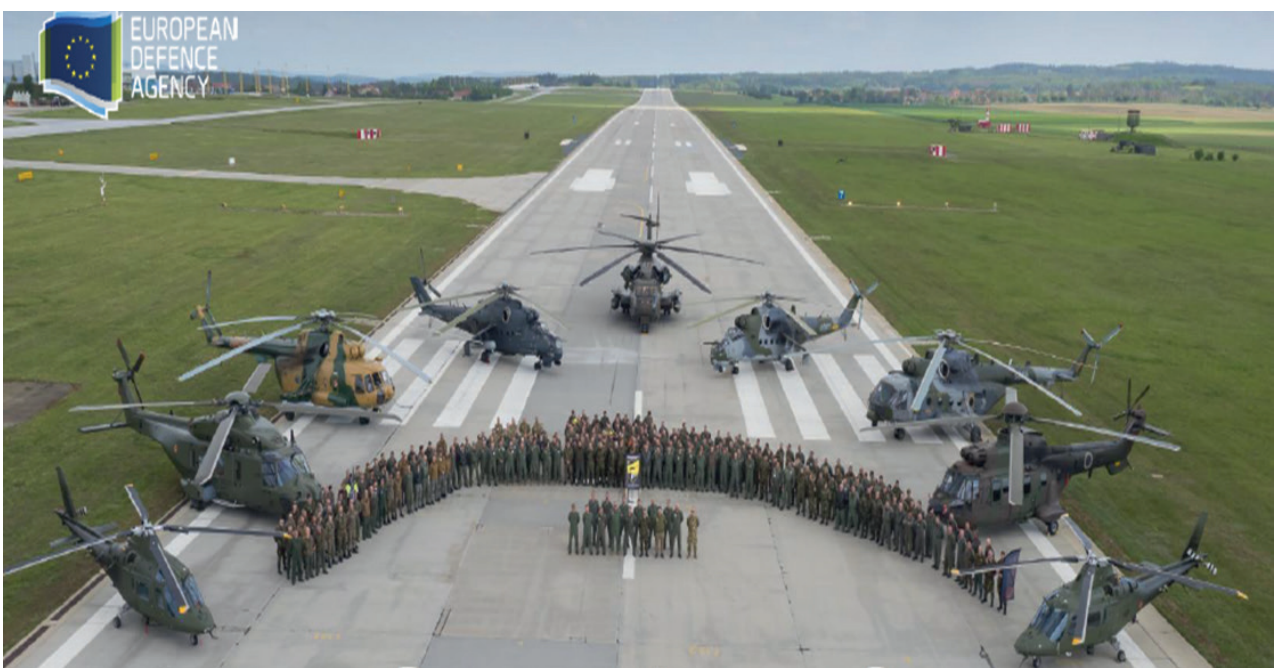

2. ábra $A z E D A$ által szervezett helikopteres kiképzés záróképe ${ }^{21}$

\section{MAGYAR RÉSZVÉTEL AZ ÜGYNÖKSÉGBEN ÉS ANNAK PROJEKTJEIBEN}

Magyarország az Ügynökség megalakulása óta jellemzően úgynevezett ernyőprogramokhoz csatlakozott, amelyeken belül különbözö projektek indultak. Az ernyőprogramban történő részvétel nagy előnye, hogy nem igényel közvetlen anyagi hozzájárulást. Egyes projektek esetén természetbeni hozzájárulást tettünk (pl. gyakorlat/képzés befogadása, oktató biztosítása, személyi állomány kiküldése), ami néha többet jelentett az Ügynökségnek, mint a közvetlen anyagi hozzájárulás. Jelenleg az alábbi programokban veszünk részt:

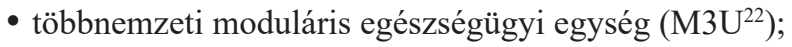

- európai légi szállítási flotta $\left(\mathrm{EATF}^{23}\right)$;

- helikoptergyakorlatok program (HEP $\left.{ }^{24}\right)$;

- összhaderőnemi telepíthető kiaknázási és elemzési laboratórium (JDEAL $\left.{ }^{25}\right)$;

- multimodális közlekedési csomópontok (M2 $\left.\mathrm{TH}^{26}\right)$;

- személymentés-irányító és -tervező tanfolyam ( $\left.\mathrm{PRCPC}^{27}\right)$;

- kormányzati müholdas kommunikáció (GOVSATCOM $\left.{ }^{28}\right)$;

- légi utántöltés $\left(\mathrm{AAR}^{29}\right)$;

- katonai légi alkalmasság (MAWA $\left.{ }^{30}\right)$.

\footnotetext{
${ }^{21}$ Készítette a szerző.

${ }^{22}$ Multinational Modular Medical Unit.

${ }^{23}$ European Air Transport Fleet.

${ }^{24}$ Helicopter Exercise Programme.

${ }^{25}$ Joint Deployable Exploitation and Analysis Laboratory.

${ }^{26}$ Multimodal Transport Hubs.

${ }^{27}$ Personnel Recovery Controller and Planner Course.

${ }^{28}$ Governmental Satellite Communication.

${ }^{29}$ Air to Air Refuelling.

${ }^{30}$ Military Airworthiness.
} 
Biztosítunk még nemzeti képviseletet a szárazföldi rendszerekkel, anyag nemekkel és rádiófrekvenciás szenzortechnológiákkal, valamint védelmi kutatás-fejlesztéssel foglalkozó munkacsoportokban és az energiabiztonsággal foglalkozó munkacsoportban is.

Magyarország egy helikopterharcászati szimpóziumnak (HTS15) adott otthont Budapesten 2015-ben. A hasonló szimpóziumokon évente részt veszünk, bár más államokhoz hasonlítva viszonylag kis létszámban - 2010-ben kettő; 2011-ben kettő; 2012-ben egy; 2013-ban kettö; 2014-ben három; 2015-ben tizenöt; 2016-ban négy; 2017-ben kettő; 2018ban három; 2019-ben három fóvel -, esetenként pedig előadót is biztosítunk a szimpózium színvonalának emelése érdekében. Hazánk egy többnemzeti helikoptergyakorlatot szervezett azzal a céllal, hogy javuljon az európai helikopterszemélyzetek interoperabilitása és települési képessége egy komplex müveleti szcenárióban, továbbá hároméves időtartamra biztosított egy fó szakértőt az EDA állományába, aki kifejezetten a helikopteres programok érdekében tevékenykedett.

A csehországi Dark Blade 2019 gyakorlaton az MH kijelölt erői is részt vettek. A magyar állomány harcászati felkészítésének fontosabb adatai:

- a Blade többnemzeti harcászati gyakorlaton első alkalommal rész vett állomány:

-6 fö helikoptervezetö;

-3 fö fedélzeti technikus;

- COMAO-feladatok végrehajtásában részt vett állomány:

- misszióparancsnok beosztásban 2 fö kapott „megfelelt”31 minősítést;

- kötelékvezetőként 1 fö kapott „megfelelt” minősítést;

- a tervezőrészlegben a kommunikációs terv elkészítéséért felelős vezetőkből 7 fö kapott „,megfelelt” minősítést;

- a kiképzési feladatok végrehajtása alatt történt elörelépések:

- müszeres repülések végrehajtása (1 fő müszeres leszállítórendszer segítségével hajtott végre bejövetelt jó látási viszonyok mellett;

- JTAC-feladatok:

- az ellenséges légvédelem elnyomása tüzérségi éleslövészettel;

- közvetlen légi támogatás éleslövészettel cseh Mi-24 harci helikopter közremüködésével;

- konvojkísérés végrehajtása belga A-109-es helikopterkötelékkel;

- levegö-föld éleslövészet végrehajtása:

- közvetlen légi támogatás - kilenc rávezetés végrehajtva;

- felhasználva 643 db 30 mm-es lőszer.

\section{A HELIKOPTERKEZDEMÉNYEZÉS PROJEKT CÉLJA}

A helikopterkezdeményezés $\left(\mathrm{HI}^{32}\right)$ 2009-ben az EDA 14 tagországa - AT, BE, CZ, DE, EL, FI, HU, IT, LU, NL, PT, SE, SI, UK - és $\mathrm{NO}^{33}$ részvételével jött létre a korábban említett hiányosságok csökkentése érdekében.

A rendelkezésre álló helikopterek hiánya válságkezelési müveletekben extrém viszonyok között - nagy távolságok, sivatagok, hegyek - és nem biztonságos környezetben ve-

\footnotetext{
31 Az EDA vezető oktatói, a mentorok döntése alapján csak „megfelelt”, illetve „,nem megfelelt” értékelés adható.

${ }^{32}$ Helicopter Initiative.

${ }^{33}$ Norvégia külön megállapodás keretében részt vehet az EDA egyes programjaiban. European Defence Agency: Member States, i. m.
} 
szélyeztetheti az egész küldetés sikerét. Az EDA nagy hangsúlyt fektet a hiányosságok csökkentésére, a képesség megfelelő szintü kialakításával, fejlesztésével, valamint az ismeretek, tapasztalatok összegyüjtése és megosztása révén az EU-országok között. A képességhiány csökkentése érdekében többnemzeti gyakorlatokat, éves szimpóziumokat, harcászati képzéseket szervez - például „képezd a kiképzőt” (Train the Trainer) program helikoptervezetők és a személyzetek vonatkozásában - és vezet le, valamint platformspecifikus szakmühelyeket vezet.

Az eredmények magukért beszélnek. 2009-2017 között Belgiumban, Finnországban, Franciaországban, Magyarországon, Olaszországban, Portugáliában és Spanyolországban a harcászati gyakorlatokra 243 helikoptert, 1590 személyzetet és több mint tízezer fónyi szárazföldi és támogató erőket telepítettek. Az EDA helikopterharcászati tanfolyamain 12 különböző országból 590 repülőeszköz-személyzet vett részt, és öt országból összesen 59 helikopteroktató végezte el a helikopterharcászati oktatók tanfolyamát.

EDA-helikopterképzés átfogó koncepcióját a Miniszteri Irányító Testület 2009 novemberében hagyta jóvá. Ennek célja, hogy keretet biztosítson a tagállamok számára a bevált gyakorlatok kidolgozására, megszilárdítására és megosztására annak érdekében, hogy az EU helikopteres társadalma megfeleljen a kor biztonsági kihívásainak az egyre bonyolultabb üzemeltetési környezetben. Az EDA számos egyedi és kapcsolt projektet nyújtott és nyújt ma is:

- helikoptergyakorlat program (HEP);

- helikopterharcászat-oktató tanfolyam $\left(\mathrm{HTIC}^{34}\right)$;

- helikopterharcászati tanfolyam $\left(\mathrm{HTC}^{35}\right)$;

- összetett légi müveleteket (COMAO) tervezö tanfolyam;

- elektronikus hadviselés (EW) tanfolyam.

\section{HEP}

A HEP keretdokumentuma a Programmegállapodás (PA $\left.{ }^{36}\right)$, amelyet 2012 novemberében írt alá 13 tagállam - ami mára 14-re növekedett. Időközben több ország (Lengyelország, Románia, Szerbia, Ukrajna) is jelezte csatlakozási szándékát. Az európai helikopterszemélyzetek alkalmazási képességeinek növelésével a HEP kiemelkedő szerepet játszik a müveletekhez szükséges telepíthető helikopterképesség növelésében. A gyakorlatok az egyéni, kötelék és többnemzeti kiképzésre összpontosítanak, a gyakorlati tapasztalatok révén erősítik az interoperabilitást, megosztják a harcászati tapasztalatokat és közös eljárásokat fejlesztenek ki. A HEP tízéves program, a közös képzés, az európai képességek és az interoperabilitás fejlesztésének szerves része.

A magyar hozzájárulás a projekthez:

- 2016-2019: 1 fő alezredes delegálása a központi tervezőcsoportba;

- 2017: gyakorlat megrendezése, befogadása (Pápa, Fire Blade 2017);

- Részvétel a Blade gyakorlatsorozaton (Italian Blade 2015, Hot Blade 2018, Fire Blade 2019);

- 2022: gyakorlat megrendezésének befogadása (tervezetten MH Pápa Bázisrepülőtér).

\footnotetext{
${ }^{34}$ Helicopter Tactics Instructor Course.

${ }^{35}$ Helicopter Tactics Course.

36 Programme Arrangement.
} 


\section{HTC}

Ez egy EDA B kategóriájú program, ${ }^{37}$ amely hét tagállamot ${ }^{38}$ foglal magában. A képzés helikopterharcászati szimulátoron valósul meg, a centrikus és modern müveleti környezet nem a pilóta, hanem a teljes helikopterszemélyzet általi megértésére összpontosít. A szimulációs technológiák alkalmazásával mind elméleti, mind szintetikus környezetben végrehajtott valósághü küldetésekből áll. A program kezdetben két évig, 2013 végéig futott, hogy megfeleljen a müveleti alkalmazások által meghatározott sürgős követelménynek. A jelenlegi PA 2022-ig szól. Évente 36 személyzetet (150 fő gépszemélyzettagot) képeznek a folyó müveletek támogatására. Ez a képzés több országban a helikopterszemélyzetek harcászati alapképzésének kötelező eleme. Az itt megszerzett alaptudást a személyzetek gyakorolhatják, elmélyíthetik saját nemzeti rendszerükben és a Blade gyakorlatok során akár többnemzeti kötelékben is.

A magyar hozzájárulás a modulhoz:

- 2012 (IS/HTC): 40 fö;

- 2013 (IS/HTC): 32 fö;

- 2018 (HTC): 10 fő (a HEP-visszatérítésből finanszírozva).

A HTC jó tudásalapot biztosított az új Thales helikopterharcászati szimulátor hadrendbe állításához.

\section{HTIC}

A HTIC a harcászatilag már teljesen kiképzett, tapasztalt személyzetek közül kiválasztott személyek harcászati oktatói képzését biztosítja: „,képezd a kiképzőt”. A képzés két fázisból áll: 4 hét földi fázis (tantermi és szimulátor), majd 3 hét repülőfázis. Az itt végzett helikopterharcászati oktatók $\left(\mathrm{HTI}^{39}\right)$ készek az EDA-rendezvényeken és a valós műveletek során is alkalmazott HEP hatályos múveleti utasítás $\left(\mathrm{SOP}^{40}\right)$ alapján a saját helikopterharcászatot oktatni. A HTI-k aktív oktatók például a COMAO- és az EW-tanfolyamokon is. Az eljárások standardizálása érdekében a HTI-k alkotják az EDA vezető oktatói csoportját $\left(\mathrm{CIT}^{41}\right)$. A CIT feladata többek között a valós müveletek és a képzési rendezvények során szerzett tapasztalatok alapján a HEP SOP karbantartása, szükség esetén annak módosítása. A HEP Blade típusú gyakorlatok során belölük állnak össze a mentorcsapatok is. Ez fontos eleme a HTI-k harcászati oktatói jártassága fenntartásának, ami az EDA CIT vezetése és felügyelete mellett valósul meg, ezzel biztosítva azt, hogy a HTI-k a saját nemzeti tevékenységük során is az aktuális EDA HEP SOP alapján, egységesen oktassanak.

Sajnos magyar oktató kiképzésére még nem volt lehetőségünk, mivel annak az előfeltétele a helikoptertechnikával történő részvétel. Megfigyelöként viszont 2 fö helikoptervezető részt vett a programokban, ami jó alapot nyújt a Thales szimulátor üzemeltetéséhez.

Az EDA 2019-ben felkérte a tagállamokat annak megvizsgálására, hogy képesek-e befogadni a HTIC repülőfázisát. Cserében a befogadó nemzetnek nem kell megfizetnie a tan-

\footnotetext{
${ }^{37}$ Az EDA A és B kategóriájú programokat szervez. Az A kategóriásban minden tagország részt vesz, a B kategóriás programokban pedig csak azok, amelyek a programban érdekeltek.

38 Ausztria, Csehország, Egyesült Királyság, Finnország, Németország, Svédország.

${ }^{39}$ Helicopter Tactics Instructor.

40 Standard Operating Procedure.

${ }^{41}$ Chief Instructor Team.
} 
folyamon történő részvételi díjat - ami jelenleg 200000 euró személyzetenként -, továbbá a Blade gyakorlatokhoz hasonlóan az EDA HTIC programja anyagi ellentételezést is nyújthat. Ezzel a lehetőséggel élve a jövőben - hosszú távon - nagy számban valósíthatnánk meg a helikopterszemélyzeteink HTI-képzését.

\section{COMAO-tanfolyam}

A COMAO tervezési tanfolyam kéthetes, egyelöre az Egyesült Királyságban tartják (legalábbis a brexitig), és lefedi a COMAO tervezését, elméletét és alkalmazását, a helikopteres müveletekre összpontosítva a HEP SOP alapján. Az elméleti részt követve a tanfolyam résztvevői napi müveleteket terveznek és jelentenek róluk. A gyakornokokat a helikopterharcászati oktatók és más kiválasztott szakemberek mentorálják és vezetik. Annak érdekében, hogy a tanulókat ösztönözzék az összfegyvernemi gondolkozásra, az oktatógárdát kiegészítik számos más repülögéptípus személyzeteivel, többek között vadászrepülö-, AWACS-, harcihelikopter- és ISR-oktatókkal. ${ }^{42}$ A napi küldetések egyre összetettebb intelligenciaalapú forgatókönyvet követnek, amely magában foglalja a képességek és a fenyegetések teljes spektrumát.

\section{EW-tanfolyam}

Az EW-képzés kéthetes időtartamú, és a kiválasztott személyzet számára biztosítja a földi telepítésü és a légi EW-rendszerek alapelméletének megértését. A tananyag magában foglalja az EW alapvető elméletét, a rádiófrekvenciás és az infravörös fenyegetéseket, a figyelmeztető rendszereket és az ellenintézkedéseket. A képzés kiterjed a földi eszközök és a légi jármüvek eszközeire, az önvédelmi rendszerek általános alkalmazási elveire, beleértve az interoperabilitás elveit is.

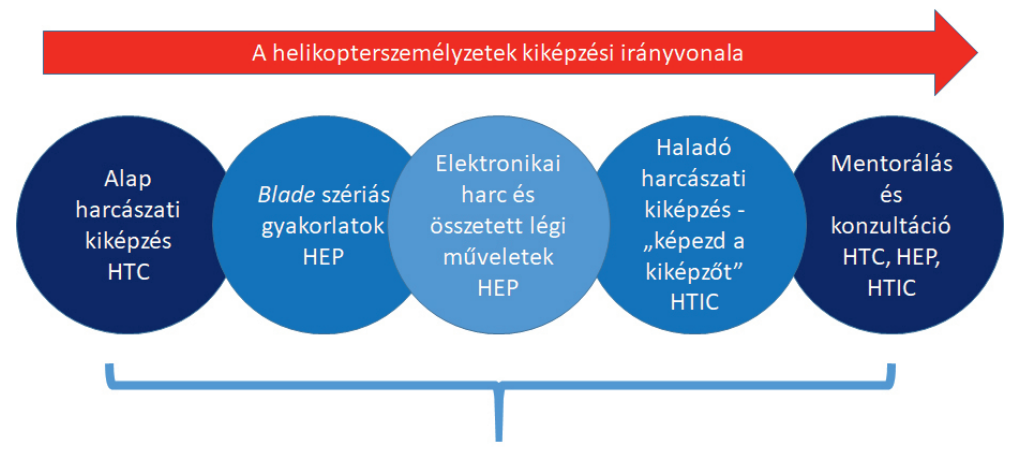

HEP SZABVÁNYOS MÜKÖDÉSI ELJÁRÁS

3. ábra Az EDA-helikopterprogramok holisztikus ábrája ${ }^{43}$ (Szerkesztette a szerzö)

\footnotetext{
${ }^{42}$ Intelligence, surveillance, reconnaissance - hírszerzés, megfigyelés, felderítés.

${ }^{43}$ Minutes of EDA Helicopter Symposium held in Brussels. 05. 11. 2019. (A szerzőnél található.)
} 


\section{A HELIKOPTERPROGRAMOK ÁTALAKÍTÁSA}

Az EDA helikopterprogramjai szervezésének és irányításának, valamint a hozzákapcsolódó harcászati képzéseknek és tanfolyamoknak új formába történő átszervezése a végéhez közeledik. Az átalakítási folyamat - melyben hazánk is érintett - 2017-ben vette kezdetét, és tervezetten két-három éven belül valósul meg az MHTC felállításával. A jelenlegi helikopterprogrammal kapcsolatos megállapodások 2022-ig szólnak. Az EDA főigazgatója egyértelmúen kinyilatkozta, hogy az Európai Harcászati Légi Szállítási Központhoz (ETAC) hasonlóan egy befogadó nemzetnek kell átadni a helikopterprogramokat is, amelyek felett a felügyeletet továbbra is az EDA gyakorolja.

Az EDA tagállamai közül Portugália jelezte, hogy a Sintra Légibázis infrastrukturálisan alkalmas és kész a központ befogadására. A tagok támogatták a portugál javaslatot az MHTC helyszínére vonatozóan, ugyanakkor még nem döntötték el, hogy a szervezet esetében kiképző központról vagy pedig egy kiképzést irányító, összehangoló központról lesz-e szó. A portugál javaslat mellett Németország is bemutatta elgondolását a helikopterharcászati képzés kialakításával és a kiképző központ befogadásával kapcsolatban.

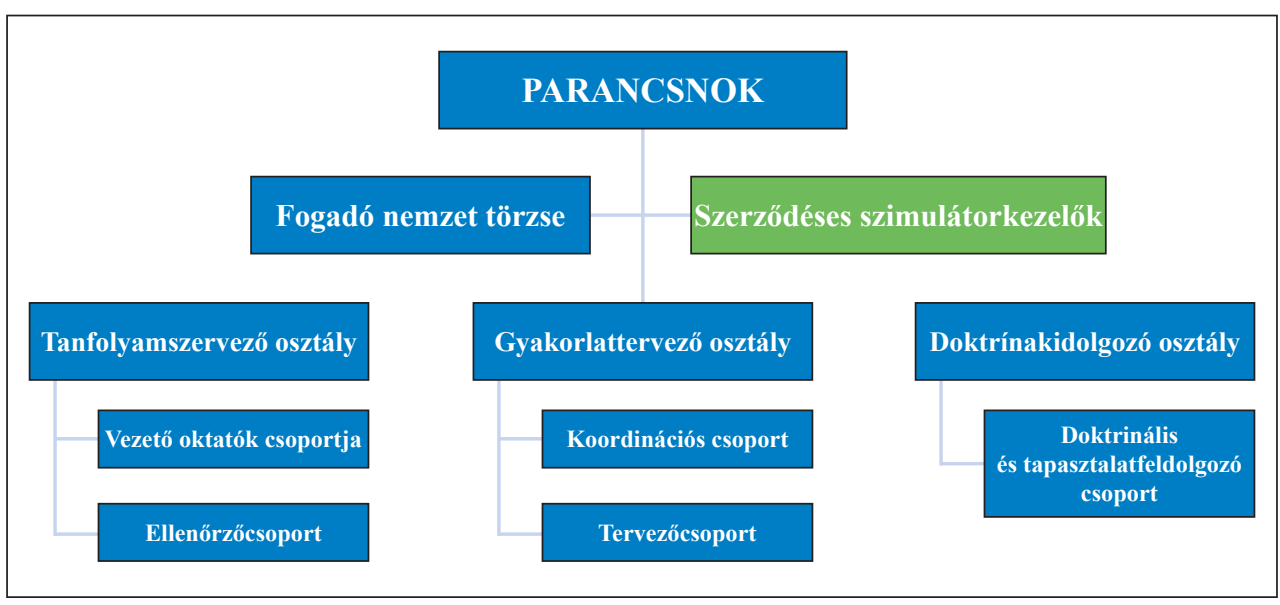

4. ábra Az MHTC irányitótörzsének tervezett felépítése ${ }^{44}$ (Szerkesztette a szerzö)

\section{MAGYARORSZÁG RÉSZVÉTELE AZ MHTC-BEN}

A tagországok kidolgozták az MHTC személyi törzsének struktúráját, a szervezet állománytáblája biztosítja a jövőbeni feladatok végrehajtását, kihívásoknak történő megfelelést.

Az MHTC felállításának helyszíne az érintett programokban (HEP, HTC, HTIC) részt vevő tagállamok egyetértésével Portugália, Sintra Légibázis. A 2021-től - az MHTC kezdeti mủveleti képességének tervezett elérésétől - 2035-ig terjedő időszakra az MHTC irányítótörzsében rotációs jelleggel betöltendő beosztások, illetve a magyar szerepvállalás megtervezésre került. Az 1. számú táblázatban látható az MHTC állománytáblában Magyarország által vállalt

\footnotetext{
${ }^{44}$ Business case for the establishment of a Multinational Helicopter Training Centre (MHTC) through an EDA CAT B project. (A szerzőnél található.)
} 
beosztások betöltésének rotációs terve, a 2. számú táblázatban pedig az MHTC által biztosított képzésekben/tanfolyamokon történő tervezett nemzeti részvétel szürkével jelölve. ${ }^{45}$

1. táblázat A magyar beosztás rotációs terve ${ }^{46}$ (Szerkesztette a szerzö)

\begin{tabular}{|c|c|c|c|c|c|}
\hline Tervezett beosztások & $\begin{array}{l}2001- \\
2023\end{array}$ & $\begin{array}{l}2024- \\
2026\end{array}$ & $\begin{array}{c}2027- \\
2029\end{array}$ & $\begin{array}{l}2030- \\
2032\end{array}$ & $\begin{array}{l}2033- \\
2035\end{array}$ \\
\hline \multicolumn{6}{|l|}{ Parancsnok (ezredes) } \\
\hline \multicolumn{6}{|l|}{$\begin{array}{l}\text { Parancsnokhelyettes, a gyakorlattervező } \\
\text { blokk vezetője (alezredes) }\end{array}$} \\
\hline $\begin{array}{l}\text { Doktrinális és tapasztalatfeldolgozó blokk } \\
\text { vezetője (alezredes/örnagy) }\end{array}$ & & $\underline{\mathrm{HU}}$ & & & \\
\hline Kiemelt oktató (alezredes/őrnagy/százados) & & & $\underline{\mathrm{HU}}$ & & \\
\hline $\begin{array}{l}\text { Tervező és koordinációs blokk vezetője } \\
\text { (alezredes/őrnagy) }\end{array}$ & & & & $\underline{\mathrm{HU}}$ & \\
\hline $\begin{array}{l}\text { Standards evaluator (alezredes/örnagy/ } \\
\text { százados) }\end{array}$ & & & & & $\underline{\mathrm{HU}}$ \\
\hline \multicolumn{6}{|l|}{ Jogászblokk vezetője (alezredes/őrnagy) } \\
\hline \multicolumn{6}{|l|}{$\begin{array}{l}\text { Beszerzési és gazdasági blokk vezetője } \\
\text { (örnagy) }\end{array}$} \\
\hline \multicolumn{6}{|l|}{ Adminisztrációs segítő (altiszt) } \\
\hline Logisztikai segítő (altiszt) & & & & & \\
\hline
\end{tabular}

${ }^{45}$ Council Decision 2004/677/EC of 24 September 2004 concerning the Rules applicable to national experts and military staff on secondment to the European Defence Agency. 07. 10. 2004. https://eur-lex.europa.eu/legal-content/EN/TXT/PDF/?uri=CELEX:32004D0677\&from=EN (Letöltés időpontja: 2020. 01. 27.)

${ }^{46}$ Minutes of the 1st Multinational Helicopter Training Centre (MHTC) project meeting held on 17 September 2019 at EDA, Brussels. (A szerzőnél található.) 
2. táblázat Nemzeti részvétel az MHTC által biztositott képzésekben/tanfolyamokban ${ }^{47}$ (Szerkesztette a szerzö)

\begin{tabular}{|c|c|c|c|c|c|c|}
\hline & HTC & HTIC & HEP & EW & СОМАО & $\begin{array}{l}\text { A nemzetek kiegészítő felajánlásai } \\
\text { a kiképzéshez }\end{array}$ \\
\hline AT & & & & & & oktató \\
\hline \multicolumn{7}{|l|}{ BE } \\
\hline \multicolumn{7}{|l|}{ CY } \\
\hline CZ & & & & & & $\begin{array}{l}\text { Többnemzeti Légi Kiképző Központ } \\
\text { (MATC) támogatása }\end{array}$ \\
\hline DE & & & & & & oktató \\
\hline EL & & & & & & meleg éghajlatú kiképzés \\
\hline ES & & & & & & HTIC nemzeti befogadása \\
\hline \multicolumn{7}{|l|}{ FI } \\
\hline \multicolumn{7}{|l|}{ HR } \\
\hline HU & & & & & & $\begin{array}{l}\text { Thales harcászati helikopterszimulátor } \\
\text { (HCTT) és a HTIC repülófázisának } \\
\text { nemzeti befogadása }\end{array}$ \\
\hline IT & & & & & & magashegyi kiképzés \\
\hline PT & & & & & & befogadó nemzet \\
\hline \multicolumn{7}{|l|}{$\overline{\mathrm{RS}}$} \\
\hline SE & & & & & & oktató és a HTIC nemzeti befogadása \\
\hline \multicolumn{7}{|l|}{ SI } \\
\hline \multicolumn{7}{|l|}{ UA } \\
\hline UK & & & & & & \\
\hline
\end{tabular}

\section{HELIKOPTERHARCÁSZATI SZIMULÁTOR ALKALMAZÁSA}

A helikopterharcászati képzés, felkészítés célja, hogy a képzésben részt vevő gépszemélyzetek megismerjék a modern helikopteres müveletek harcászati és elektronikai elemeit, a kapott harcfeladat kidolgozásának és az azzal kapcsolatos eligazítások rendjét olyan mértékben, hogy nemzeti és többnemzeti kötelékben is sikeresen végrehajthassák a kitüzött feladatot.

A harcászati szimulátoros felkészítés során az a feladat, hogy az elméleti oktatás alatt elsajátított témakörök feladatközpontú formában begyakorlásra kerüljenek. Ez azt jelenti, hogy egy konkrét feladat vételét követően a helikopterszemélyzetek legyenek képesek a felkészülés során kapott feladat értelmezését követően önállóan elkészíteni a végrehajtási tervet, azt ismertetni, végül a feladatot biztonságosan és eredményesen végrehajtani. A har- 
cászati felkészítés során jelentős költséget lehet megtakarítani szimulátorberendezések alkalmazásával.

Az EDA által alkalmazott angliai Linton-on-Ouse-ban lévő helikopterharcászati szimulátor igénybevétele az Egyesült Királyságnak az EU-ból történő kiválása miatt problémássá válhat, ezért a szimulátor további alkalmazásával, esetleges áthelyezésével vagy pótlásával kapcsolatosan a HTC többi tagországának (Ausztria, Csehország, Finnország, Németország, Norvégia, Svédország) át kell dolgozniuk a további terveiket.

A Magyar Honvédség jelenlegi és a közeljövőben hadrendbe álló helikoptertechnikai eszközeit üzemeltető személyzetek harcászati felkészítéséhez elengedhetetlen a részvétel az EDA szakmai felügyelete alatt álló harcászati programokon, tanfolyamokon (EW, COMAO, HTC, HTIC és HEP), és azokon hazánk a jövőben is részt kíván venni.

Az elektronikai hadviselés, valamint a különböző fegyvernemek harccsapatainak bevetéstervezői felkészítéseken szerzett elméleti és gyakorlati tudás elmélyítéséhez, gyakoroltatásához kiváló szakmai és költséghatékony felkészítési lehetőséget biztosít az MH 86. Szolnok Helikopter Bázison hadrendbe állított Thales szimulátor. A berendezés hosszú távon történő eredményes használatához elengedhetetlen az azt üzemeltető szakemberek, kulcsoktatók tudásának frissítése, aktualizálása az említett EDA-képzéseken történő részvételekkel.

A szolnoki Thales szimulátorberendezés grafikája megfelel a követelményeknek, az objektumok megfelelően részletesek ahhoz, hogy a különféle fegyverrendszerek felismerhetőek legyenek. A szimulátorberendezés repüléstechnikailag egyszerüsített, a vezetési technika nem kötődik a helikopter aerodinamikájához, így a személyzet - mindamellett, hogy el kell kerülnie a földdel, illetve más repülőeszközökkel és tereptárgyakkal való ütközést - megfelelö figyelmet tud fordítani a feladat harcászati, együttmüködési elemeire. A helikoptertípusok navigációs, rádiótechnikai és fegyverzetpaneljei követik a típushoz rendszeresített berendezéseket kinézetben és képességekben egyaránt, így a szimuláció során megszerzett automatizmusok a valós végrehajtás során is alkalmazhatóak. A szimulátorberendezés fegyverzetszimulációja nagymértékben valóságos és naprakész, így a helikoptertechnikához rendszeresített támadó- és védelmi berendezések megfelelő, harcszerü használata kellöképpen begyakorolható. A szimuláció során a virtuális környezetben megjelenő ellenséges erők és technikák a betáplált doktrinális elvek alapján képesek önállóan ténykedni, célt felderíteni és tüzet vezetni, de a betáplált harcászati szituációt a számítógép-animátor képes bármikor változtatni.

Összességében elmondható, hogy az MH 86. Szolnok Helikopter Bázison hadrendbe állított Thales szimulációs berendezés alkalmas a helikopterharcászati ismeretek magas szinten történő elsajátítására és begyakorlására.

A Magyar Honvédség helikopteres alegységei harcászati felkészítésének az iránya egybeesik az EDA helikopteres projektjeinek az új MHTC szervezetébe történő átszervezésének terveivel. A Magyar Honvédségben a helikopterharcászati kiképzést mint képességkiépítést javasolt úgy megtervezni - az előretolt harctéri repülésirányító (JTAC $\left.{ }^{48}\right)$ képesség kiépítéshez hasonlóan -, hogy hazánk akár önállóan, illetve a képesség elemeit/ moduljait felajánlva regionális szinten is képes legyen a szomszédos, illetve partnerországokkal együttmüködni.

\footnotetext{
48 Joint Terminal Attack Controller.
} 


\section{JAVASLAT AZ MH TOVÁBBI RÉSZVÉTELÉRE AZ EDA HELIKOPTERHARCÁSZATI PROGRAMJAIN, TANFOLYAMAIN}

Az elektronikai harcászaton és a különböző fegyvernemek harccsapatai bevetéstervezőinek felkészítéseken szerzett elméleti és gyakorlati tudása elmélyítéséhez, gyakoroltatásához kiváló szakmai és költséghatékony felkészítési lehetőséget biztosít a 2019 elején az MH 86. Szolnok Helikopter Bázison hadrendbe állított Thales szimulátorberendezés. A berendezés alkalmazásához nélkülözhetetlenek azok a repülö-hajózó szakemberek, akik mind szakmai felkészültségük, mind a műveleti területeken szerzett gyakorlati tapasztalataik alapján alkalmasak a szimulátor adatbázisa és az alkalmazott szcenáriók összeállítására, a rendszer üzemeltetésére a kiképzés minden oldalú támogatása céljából. Ezért az említett szakemberek, kulcsoktatók tudásának frissítése, aktualizálása elsősorban a fent említett EDA-képzéseken, gyakorlatokon lehetséges.

A nemzeti szerepvállalás további növelése, kiszélesítése érdekében az alábbi felkészítési rendezvényeken történő részvétel javasolt:

- további részvétel EW- és COMAO-tanfolyamokon 2019-2022-ben;

- részvétel 2020-ban a belga-holland közös rendezésü Swift Blade gyakorlaton, valamint a további (például a 2021. évi portugáliai) Blade gyakorlatokon;

- a HTIC gyakorlati repülőfázisának befogadása Pápa Bázisrepülötérre 2021-től;

- egy Blade többnemzeti helikopterharcászati gyakorlat nemzeti befogadása 2022-re.

\section{Részvétel EW- és COMAO-tanfolyamokon 2019-2022-ben}

A kéthetes felkészítések elengedhetetlen alapot biztosítanak a gépszemélyzetek, kötelékparancsnokok részére a bevetések, müveletek tervezéséhez. A tanfolyamok költségét az EDA HEP költségvetése biztosítja. A képzés jó lehetőséget biztosít arra is, hogy azok a helikoptervezetök, oktatók, akik a képzésen részt vettek, átadják szerzett tapasztalataikat a szolnoki HCTT szimulátorberendezése üzemeltetéséhez, a szcenáriók összeállításához.

\section{Részvétel a belga-holland rendezésű Swift Blade gyakorlaton 2020-ban}

Az EDA HEP előzetes tervében a soron következő Blade típusú gyakorlat befogadását Belgium és Hollandia közösen vállalta. A Benelux-államok két országa az egyeztetéseket követően a közös határhoz közeli Gilze-Rijen Légibázist jelölte ki a gyakorlat helyszínéül. A gyakorlaton történő részvétel ismételten kiváló felkészítési, gyakoroltatási lehetőséget biztosít 2020-ban is a helikopterszemélyzetek harcászati képességének fejlesztésében.

\section{Részvétel a Portugália által befogadott Hot Blade 2021 gyakorlaton}

A portugál gyakorlat kiváló lehetőséget nyújt a magashegyi, a meleg éghajlati és a poros területen végrehajtott repülési elemek begyakorlására, ami elengedhetetlen kelléke egy különleges müveleti légi csoportba $\left(\mathrm{SOATU}^{49}\right)$ kijelölt személyzet felkészítésének is.

\footnotetext{
49 Special Aviation Air Task Unit.
} 


\section{A HTIC gyakorlati fázisának befogadása Pápa Bázisrepülőtérre 2021-től}

A képzés gyakorlati fázisának Magyarországra történő telepítése nem újszerü gondolat, 2017 októberében már felmerült tervezési szinten. Az MHTC tagjaként közép-európai kiképző alközpontjaként az EDA igényeit is kielégítené. A tantermi és a szimulátoros képzés Szolnokon a Thales szimulátor bevonásával tervezve, a repülőharcászati kiképzés és minősítés a Bakony Harckiképző Központ gyakorlótereire (újdörögdi romváros, Hajmáskér), a valós logisztikai biztosítás pedig Pápa Bázisrepülőtér támogatására épül.

A svédországi repülőkiképzés rendkívül magas költsége - eddig 200000 euró személyzetenként (ez a jövőben 140000 euróra csökken) -, valamint a képzés helyszínéül használt, a svédországi Vidsel gyakorlótér mintegy 2000 km-es távolsága Szolnoktól aránytalanul nagy terhet jelentett pénzügyi és technikai biztosítás vonatkozásában is, ezért nem volt célszerü e képzés igénybevétele. Hasznosabbnak látszik a képzés kiváltása külföldi oktatók bevonásával magyarországi bázison (HTIC, a repülőfázis magyarországi befogadásával), felhasználva a kiváló lőtéri körülményeket.

A felkészítés tervezésében, előkészítésében a szakirányú állománnyal történt egyeztetést követően az a szakmai javaslat született, hogy 2021-re egy többnemzeti helikopterharcászati gyakorlatot tervezünk be a Nemzetközi Gyakorlatok és Kiképzési Rendezvény Programok 2020-2024. évi tervébe a Pápa Bázisrepülőtérre, amelynek keretében gyakorlati repüléssel és éleslövészettel egybekötött felkészítés során kerülnek begyakoroltatásra és minősítésre a helikopterszemélyzetek.

\section{A Blade többnemzeti helikopterharcászati gyakorlat nemzeti befogadása 2022-ben}

2019 elején az EDA helikopteres programjainak a vezetője felkérte a HEP-ben részt vevő társnemzeteket, hogy finn és svéd kérésre vizsgálják meg annak a lehetőségét, hogy mely ország hajlandó a 2022. évi Blade gyakorlat befogadására, a gyakorlattal kapcsolatos nemzeti támogatás biztosítására. Vagyis az a kérdés, hogy a 2012-ben aláírt Programmegállapodásban (PA) a két ország által vállalt 2022. évi gyakorlat megrendezését át tudja-e vállalni más nemzet. A két skandináv ország az előzetes elgondolások alapján a gyakorlatot a svédországi Vidsel gyakorlótérre tervezte, ami azonban jelentős logisztikai kihívást jelentene a közép- és nyugat-európai országok részére, és nem érné el a gyakorlat a kitüzött célját, a minél több nemzet részvételét. A gyakorlatra történő jelentkezéssel kapcsolatos érdektelenség elgondolkodtatta a rendezőket, és ezért ajánlották fel más ország részére a rendezés jogát. Az EDA az ilyen gyakorlatot befogadó nemzet részére 150000 eurót utal át a rendezés támogatására, amely felett az adott ország szabadon rendelkezik, így például a költségdíjas képzéseket, felkészítéseket is tudja belőle finanszírozni. Magyarország 2017-ben már teljesítette a PAban vállalt kötelezettségét, illetve a gyakorlat végrehajtását követő nagyon pozitív visszajelzésekre hivatkozva több ország is, közöttük Ausztria és Szlovénia egyöntetűen támogatta a magyar rendezést. 


\section{ÖSSZEGZÉS}

Európa biztonsága és védelme nemzeti érdek, kulcsfontosságú prioritás. Ennek fényében Magyarország kiemelten támogatja az Európai Unió Közös Biztonság- és Védelempolitikája területén történő együttmúködés elmélyítését. A magyar értelmezés szerint az EDA a NATO európai pillérét erősíti, és hozzájárul Európa védelméhez a déli kihívásokkal (például migráció, terrorizmus) szemben a határainkon és a közvetlen szomszédságunkban. Az állandó strukturált együttmüködés sikeres végrehajtása hosszú távon hozzájárul az európai védelmi képességek fejlesztéséhez, a képességhiányok csökkentéséhez és az EU ambíciószintjének eléréséhez. Emellett elősegítheti az európai erők nagyobb fokú telepíthetőségét, rugalmasságát és interoperabilitását. Az MH részvétele az EDA-projektekben hozzájárul a Magyar Honvédség képességeinek fejlesztéséhez, amit a NATO keretei között folyó védelmi képességfejlesztéssel összehangolva hajt végre.

A fent említett EDA-projektek nagymértékben hozzájárulnak a nemzeti forgószárnyas harcászati kiképzési képesség fejlesztéséhez. Ha a helikopterszimulátorunk összeköthető lesz más nemzetek rendszereivel, az még inkább elösegíti az interoperabilitás és a harcászati kiképzés magas színvonalon tartását.

\section{FELHASZNÁLT IRODALOM}

Ált/24. MH Kiképzési Doktrína. Magyar Honvédség, 2012.

Business case for the establishment of a Multinational Helicopter Training Centre (MHTC) through an EDA CAT B project. (A szerzőnél található.)

Council Decision 2004/677/EC of 24 September 2004 concerning the Rules applicable to national experts and military staff on secondment to the European Defence Agency. 07. 10. 2004. https:// eur-lex.europa.eu/legal-content/EN/TXT/PDF/?uri=CELEX:32004D0677\&from=EN

Council Decision 2011/411/CFSP of 12 July 2011 defining the statute, seat and operational rules of the European Defence Agency and repealing Joint Action 2004/551/CFSP. Official Journal of the European Union, 13. 07. 2011.

Council Joint Action 2004/551/CFSP of 12 July 2004 on the establishment of the European Defence Agency. Official Journal of the European Union, 17. 07. 2004. https://eur-lex.europa.eu/ legal-content/EN/TXT/PDF/?uri=CELEX:32004E0551\&from=EN

European Defence Agency: Helicopter Initiatives. 02. 07. 2017. https://www.eda.europa.eu/what-wedo/activities/activities-search/helicopter-initiatives

European Defence Agency: Member States. https://eda.europa.eu/Aboutus/who-we-are/member-states

European Defence Agency: Organisation. https://www.eda.europa.eu/Aboutus/who-we-are/Organisation

European Defence Agency: Together for a stronger Europe. 2012. https://www.eda.europa.eu/docs/ eda-publications/eda-corporate-brochure, DOI: 10.2836/12612

Minutes of EDA Helicopter Symposium held in Brussels. 05. 11. 2019. (A szerzőnél található.)

Minutes of the 1st Multinational Helicopter Training Centre (MHTC) project meeting held on 17 September 2019 at EDA, Brussels. (A szerzőnél található.) 